\title{
Vaccine-induced immune responses against SARS-CoV-2 infections
}

\author{
Mandeep Garg${ }^{*}\left(\mathbb{0}\right.$, Muniraju Maralakunte ${ }^{1}$, Yashwant Kumar², Harish Bhujade ${ }^{1}$, Inder Paul Sehgal ${ }^{3}$, \\ Vikas Suri ${ }^{4}$, Suruchi Garg ${ }^{5}$ \\ ${ }^{1}$ Department of Radiodiagnosis \& Imaging, Post Graduate Institute of Medical Education and Research (PGIMER), Chandigarh \\ 160012, India \\ ${ }^{2}$ Department of Immunopathology, Post Graduate Institute of Medical Education and Research (PGIMER), Chandigarh \\ 160012, India \\ ${ }^{3}$ Department of Pulmonary Medicine, Post Graduate Institute of Medical Education and Research (PGIMER), Chandigarh \\ 160012, India \\ ${ }^{4}$ Department of Internal Medicine, Post Graduate Institute of Medical Education and Research (PGIMER), Chandigarh \\ 160012, India \\ ${ }^{5}$ Department of Dermatology, Aura Skin Institute, Chandigarh 160012, India
}

*Correspondence: Mandeep Garg, Department of Radiodiagnosis and Imaging, Post Graduate Institute of Medical Education and Research (PGIMER), Chandigarh 160012, India. gargmandeep@hotmail.com

Academic Editor: Wangxue Chen, National Research Council Canada, Canada

Received: May 25, 2021 Accepted: November 1, 2021 Published: December 31, 2021

Cite this article: Garg M, Maralakunte M, Kumar Y, Bhujade H, Sehgal IP, Suri V, et al. Vaccine-induced immune responses against SARS-CoV-2 infections. Explor Immunol. 2021;1:356-73. https://doi.org/10.37349/ei.2021.00024

\begin{abstract}
Vaccination against coronavirus disease 2019 (COVID-19) is one of the most effective tools to curb the pandemic. Multiple vaccine candidates based on different platforms are available for emergency use presently. However, in common all the vaccines target spike protein, which is a dominant immunogen of severe acute respiratory syndrome corona virus 2 (SARS-CoV-2). Adequate immunogenicity and efficacy are demonstrated by many of the vaccines in clinical phase III trials. The emergence of the new variant of concern is believed to be associated with less susceptibility to the post-infection or post-vaccination mounted immunity. It is a global concern currently threatening the progression of the vaccination drive. Nevertheless, the results of the presently available phase III clinical trials promote COVID-19 vaccination to prevent disease severity and COVID-19 related deaths. Cross-immunity towards the new variants of concern especially against the South African variant is yet to be explored and managed adequately.
\end{abstract}

\section{Keywords}

Severe acute respiratory syndrome corona virus 2, coronavirus disease 2019, vaccine, immune response, pandemic

\section{Introduction}

Vaccination against severe acute respiratory syndrome coronavirus 2 (SARS-CoV-2) is the most pursued method to combat coronavirus disease 2019 (COVID-19) pandemic. Soon after a detailed exploration of

(C) The Author(s) 2021. This is an Open Access article licensed under a Creative Commons Attribution 4.0 International License (https://creativecommons.org/licenses/by/4.0/), which permits unrestricted use, sharing, adaptation, distribution and reproduction in any medium or format, for any purpose, even commercially, as long as you give appropriate credit to the original author(s) and the source, provide a link to the Creative Commons license, and indicate if changes were made. 
the genetic sequence of SARS-CoV-2, various scientists and biopharmaceuticals collaborated to investigate the possible vaccine candidates against COVID-19. Currently, there are 87 vaccine candidates in clinical development, and 187 vaccine candidates in preclinical development [1]. The development of COVID-19 vaccines is progressing at an unprecedented pace, with the transition into immediately advanced trial phases seamlessly. Keeping in mind the safety of trial participants, the trials were assessed for the safety and efficacy of vaccines right from the beginning by independent teams before approving the advanced phases of clinical trials [2]. The present article reviews the immunologic basis for the development of COVID-19 vaccines, research evidence advocating for COVID-19 vaccines; and different vaccine platforms and their immunogenicity against SARS-CoV-2. Lastly, we also provide an overview of the new variants of SARS-CoV-2 and the safety profile of vaccines against COVID-19.

\section{Immunologic basis for the development of COVID-19 vaccines}

SARS-CoV-2 is a large, enveloped virus containing segmented, positive sense, single-stranded RNA (ssRNA). It belongs to the family Coronaviridae and the order Nidovirales. It is composed of four structural proteins: spike (S), envelope (E), membrane (M), and nucleocapsid (N). The spherical surface of the virus is decorated by club-shaped spike projections called S protein [3]. S protein is a class I, trimeric, fusion protein that helps the virus to adhere to the host cell surface receptor $[4,5]$. It comprises two subunits S1 and S2 (Figure 1). The S1 subunit holds receptor-binding domain (RBD) which recognizes and facilitates the adhesion of the virus to its angiotensin-converting enzyme 2 (ACE-2) receptor expressed by host cells. The S2 subunit comprises the fusion peptide, heptapeptide repeat (HR) sequence 1 and 2, a transmembrane domain, and cytoplasm domain. By causing membrane fusion, it facilitates viral entry into the host cell for replication [4-6]. Genomic studies have revealed RBD and S2 subunit protein as highly conserved antigenic determinants of SARS-CoV-2 [7, 8]. It has been shown that antibodies directed against $S$ protein only can neutralize the virus and prevent infection [9]. This fueled the idea of the development of universal vaccination targeting the $S$ protein. However, non-neutralizing antibodies to other structural proteins (E, M, and/or N proteins) and weakly neutralizing antibodies are also likely to have a role in the antiviral immune response. Hence, the inclusion of these proteins as vaccine antigens may also help to induce a more balanced response in the form of both humoral and T cell-mediated immunity. Also, the inclusion of viral enzymes such as RNA-dependent, RNA polymerase may further ensure that the vaccine has a widespread action especially in the case of emerging variant strains as these proteins are also highly conserved in the virus $[10,11]$.

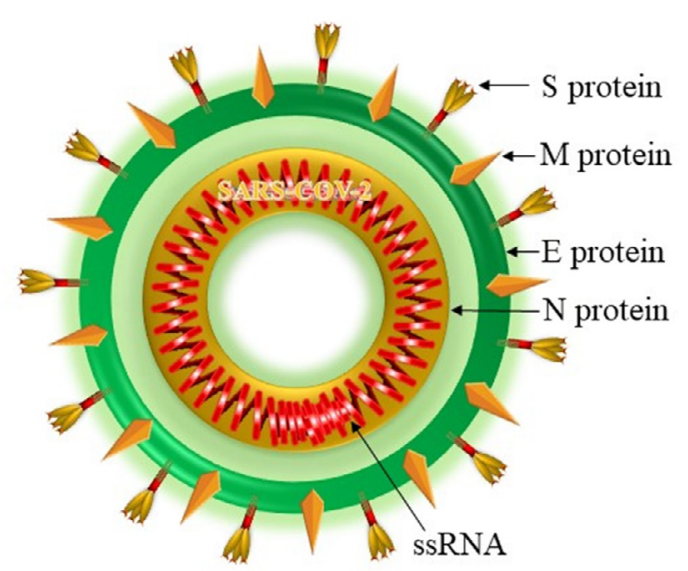

SARS-COV-2

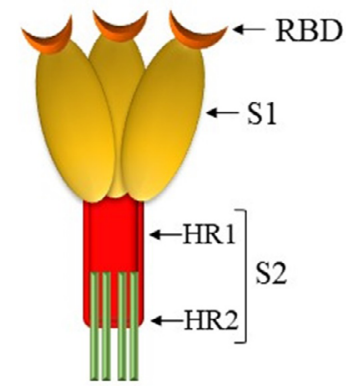

Spike (S) protein subunits

Figure 1. Schematic representation of the SARS-CoV-2 structure and its S protein subunits

\section{Immune response against SARS-CoV-2}

The SARS-CoV-2 infection has been shown to activate both innate and adaptive immune systems [12]. After the entry of SARS-CoV-2 into the body and its binding to ACE- 2 receptors, expressed by host type- 2 
pneumocytes and also macrophages and T cells, the virus starts its proliferation $[13,14]$. Soon the innate immune arm responds and pattern recognition receptors (PRR) like endosomal Toll-like receptors (TLRs) and retinoic acid-inducible gene (RIG) like receptors. The binding of PRR stimulates certain adapter proteins which in turn activate downstream transcription factors, e.g., interferon regulatory factor (IRF) causing initiation of production and release of interferons (IFNs). In addition, PRRs also activate other signaling molecules such as nuclear factor-kappaB (NF- $\mathrm{kB}$ ), and activator protein 1 (AP-1) that lead to the release of many cytokines, i.e., interleukin 6 (IL-6), monocyte chemotactic protein-1(MCP1), chemokine (C-X-C motif) ligand 1 (CXCL1), CXCL5, and CXCL10/interferon-gamma-inducible protein 10 (IP-10) and chemokines $[15,16]$. The chemokines released then recruit more innate immune cells predominantly macrophages, dendritic cells (DCs), natural killer (NK) cells, and neutrophils. These cells then produce more chemokines including IP-10, monokine induced by interferon-gamma (MIG), and MCP-1 that attract lymphocytes and thus initiate the adaptive immune response. Also, the SARS-CoV-2 S protein binding ACE2 receptors and recognition via TLRs, e.g., TLR3, 7, and 8 initiate activation of signaling pathways such as interferon regulatory factor 3 (IRF3), NF- $\kappa \mathrm{B}$, Janus kinase/signal transducer and activator of transcription (JAK/STAT) leading to IFN type I and other cytokines production by the cells like monocytes which in turn leads to differentiation of $\mathrm{T}$ cells towards $\mathrm{CD} 4 \mathrm{~T}$ helper cells. Though cytokines released under the influence of $\mathrm{NF}-\kappa \mathrm{B}$ facilitate optimum immune response in SARS-CoV-2 infection it exaggerates the inflammation thereby leading to excessive lung injury [17].

Cytokine profile in SARS-CoV-2 infection is unique as it causes the release of pro-inflammatory cytokines, e.g., IL-1B, IL-1 receptor antagonist, IL-6, IL-7, IL-8, IL-9, tumour necrosis factor alpha (TNF- $\alpha$ ), basic fibroblast growth factor (FGF), granulocyte colony-stimulating factor (G-CSF), granulocyte-macrophage colony-stimulating factor (GM-CSF), IFN $\gamma$, MCP-1, macrophage inflammatory protein-1alpha (MIP-1 $\alpha$ ), MIP-1 $\beta$, platelet-derived growth factor (PDGF), vascular endothelial-derived growth factor (VEGF), etc, which facilitate evasion mechanisms of SARS-CoV-2 such as skipping IFNs production and other antiviral actions [18]. There is a profound increase in IL-6 in response to SARS-CoV-2 which binds to its surface as well as soluble receptor gp130 and further enhances the activation of the JAK/STAT pathway. SARS-S protein decreases the expression of ACE-2 receptor causing increased local production of angiotensin II which in turn further enhances the production of IL-6 by activating the JAK/STAT pathway [19]. Hence, they both complement their functions and initiate a vicious cycle of inflammation [20].

Within a few days of SARS-CoV-2 infection, the adaptive immune arm also becomes functional predominantly in the form of generation of neutralizing antibodies generated by $\mathrm{B}$ cells as a result of $\mathrm{T}$ cell-dependent germinal center interactions. These antibodies by binding to the viral envelope or capsid antigens efficiently neutralize the virus in their extracellular stage and prevent their entry into the host cells. Also, these antibodies may opsonize the viruses and facilitate their phagocytosis. However, virus, if evades capture by the neutralizing antibodies and succeeds in getting entry into host cell then $\mathrm{T}$ cell-mediated immunity, counteracts the virus multiplication. The $\mathrm{CD}^{+} \mathrm{T}$ cells by recognizing the virus antigen take the charge and by their cytotoxic actions they kill and eliminate the virus [21]. Meanwhile, viral antigen captured by the antigen-presenting cells (APCs) is processed and presented to $\mathrm{CD} 4^{+}$helper $\mathrm{T}$ cells resulting in activation of $\mathrm{T}$ cell-mediated adaptive immune response to combat the infection [22]. There is the further release of inflammatory cytokines and differentiation of cytotoxic $\mathrm{CD} 8^{+} \mathrm{T}$ cells. The helper cells also activate $\mathrm{B}$ cells thereby causing the production of antiviral immunoglobulin G (IgG), $\operatorname{IgM}$, and $\operatorname{IgA}$ antibodies. Also, there is the secretion of a large amount of pro-inflammatory cytokines, e.g., TNF- $\alpha$, IL- 6 , and IFN- $\alpha / \gamma$, by both innate and adaptive immune cells. This cytokine storm as a result of the accumulation of different immune cells in the lung causes alveolar damage and edema which is responsible for hypoxia and acute respiratory distress syndrome (ARDS) [23].

When the virus is cleared, SARS-CoV-2 specific effector cells undergo apoptosis or are reprogrammed to differentiate into $\mathrm{CD} 4^{+}$and $\mathrm{CD} 8^{+}$memory $\mathrm{T}$ cells. They persist in the body for years and can elicit an efficient immune response on reinfection. This forms the basis of the use of a vaccine that targets these cells and helps in rapid viral clearance after the second exposure. 
Studies targeting serological evaluation reveal the production of antibodies against $\mathrm{S}, \mathrm{M}, \mathrm{E}$, and $\mathrm{N}$ proteins of SARS-CoV-2. However, the neutralizing antibodies which block virus interaction with the receptor are induced only against the S protein (Figure 2) [24]. The studies have shown fatal outcomes with SARS patients having deficient antibodies against $S$ protein [25]. S protein or its different regions, therefore, are pragmatic immunogen(s) to be used in vaccination against COVID-19 infection. Further, studies also noted the short-term nature of neutralizing antibodies against SARS-CoV-2. The neutralizing antibody response on average peaked at 4 months and thereafter showed a declining trend [24].

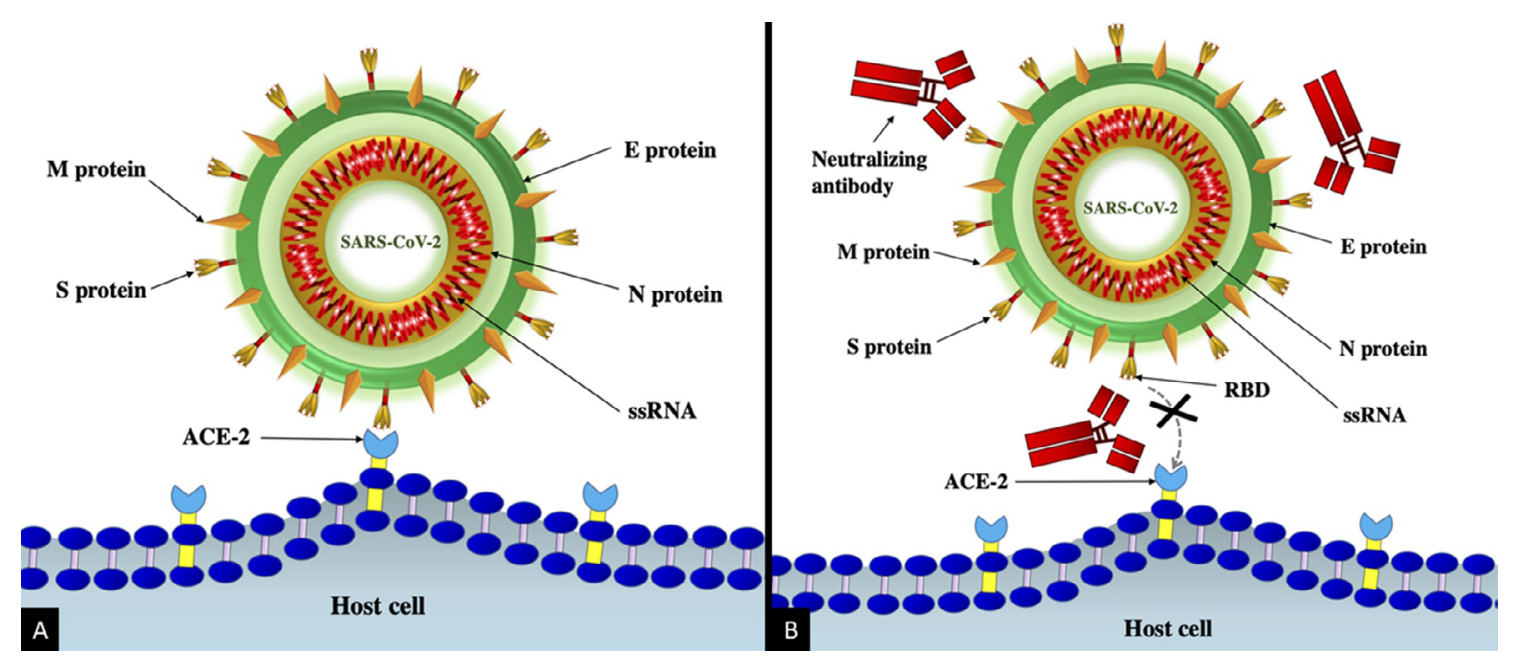

Figure 2. Schematic representation of the SARS-CoV-2 $S$ protein binding with the ACE-2 receptors of host cells with no neutralizing antibodies in sera (Figure 2A), while circulating neutralizing antibodies against the SARS-CoV-2 S protein prevent binding and internalization of the SARS-CoV-2 (Figure 2B)

Previous SARS epidemic studies have shown persistence of $\mathrm{CD}^{+}$memory $\mathrm{T}$ cells for years together on follow-up, adding to the complimentary protective role in the long term [24]. The DNA-based vaccine designs have reported the generation of both $\mathrm{B}$ and $\mathrm{T}$ cell responses against SARS infection in animal models [26, 27]. A vaccine having encapsulated mRNA encoding full-length S protein of SARS-CoV-2 has also been developed [28]. Few studies have also advocated for the mucosal immune response (secretory IgA) against effective prevention of coronavirus infection at the entry site. It has led to the development of intranasal (IN) vaccine application [29]. However, studies showed suboptimal systemic immune response following IN vaccination. All these studies make one realize that an ideal universal vaccine design against SARS-CoV-2 must elicit mucosal, humoral, cellular, and long-term memory B cell immune response and it also should possess cross-protective immunity (against S2 subunit) to deal with SARS-CoV variants [30].

\section{Immune response to COVID-19 vaccines}

The efficacy of any vaccine is determined by the strength of the immune response generated after vaccination. So far most of the approved vaccines for COVID-19, e.g., nucleic acid-base, recombinant viral vector, inactivated virus all have been claimed to elicit strong humoral as well as cellular responses. Their main goal is to generate SARS-CoV-2 neutralizing antibodies as well as memory cells [31]. The recombinant viral vectors work like an endogenous antigen. Their cellular response is exhibited through APCs like DCs which capture these molecules, break them into smaller peptides and generate antigenic peptides. These peptides along with major histocompatibility complex class I (MHC-I) then presented to naive T cells and help in their priming and hence the initiation of the adaptive immune response against the virus [30]. The activated $T$ cells then stimulate B cells which differentiate into plasma cells to produce neutralizing antibodies. Also some of the B cells rather than producing antibodies become quiescent and later on differentiate into memory B cells and generate immunological memory against the virus [32]. These long-lived plasma cells travel to reside in bone marrow niches and can continue to produce antibodies for decades. Primed T cells also promote activation of cytotoxic cells which helps in the rapid clearance of virus and infected cells. Similarly, CD8 ${ }^{+}$ memory $\mathrm{T}$ cells produced can proliferate rapidly after pathogen encounters and modulate the elimination of 
infected cells. This has been shown by the detection of CD4+ memory cells and CD8 ${ }^{+} \mathrm{T}$ cells primed for $\mathrm{S}, \mathrm{N}$, and M proteins in recovered patients of COVID-19 [33]. Similarly, these patients also have detectable levels of neutralizing antibodies against these proteins [34].

\section{Vaccination in immunocompromised individuals}

Most vaccines available for COVID-19 don't use any live virus rather they use killed, inactivated, purified organism or their protein and/or polysaccharide components hence their replication in the recipient is a remote possibility even in immunocompromised individuals. However, extra precautions may be required in case a live vaccine becomes available for COVID-19 particularly in patients with T cell defects. An important concern in these individuals is the generation of the weak immune response against the vaccine and that also depends on the type of immune defect, age of the patient, therapy, and probably type of vaccine received [35]. Also, infections are a common cause of mortality, and the efficacy of the COVID-19 vaccine in these patients is unknown hence there is much apprehension in the general population regarding safety and associated risks.

Most patients in this category are those having an immune-mediated inflammatory disease or those on immunosuppressive drugs due to one or another reason. Patients of autoimmune disorders fortunately so far have not shown an increased risk of COVID-19 complications but a recent report on Pfizer/BioNTech and AstraZeneca/Oxford COVID-19 vaccines showed after the first dose only 70\% of immunocompromised patients had coronavirus antibodies in contrast to $95 \%$ of their non-immunosuppressed counterparts. Also, the vaccine was effective against symptomatic infection in only $4.0 \%$ of immunocompromised subjects however after the second dose the effectiveness increased to $73.0 \%$ with Pfizer and $74.6 \%$ with AstraZeneca [36].

The patients with autoimmune disorders particularly those on Rituximab or methotrexate have also been found to have diminished immune response after vaccination particularly the low production of neutralizing antibodies against the neoantigens [31]. Recent data has also shown lower antibody responses against the SARS-CoV-2 S protein in recipients of solid-organ transplantation, patients on hemodialysis, chemotherapy, or immunotherapy for malignancies, and those given infliximab for inflammatory bowel disease [37-43].

\section{COVID-19 vaccination in pregnancy and lactation}

SARS-CoV-2 infection during pregnancy is likely to be severe and may result in preterm delivery or even pregnancy loss. In view of lack of enough evidence and data on safety of vaccination during pregnancy, the WHO till the beginning of 2021 was hesitant in recommending vaccination during pregnancy. However, due to persistent support by the various professional bodies in favor of vaccination of pregnant females including the American College of Obstetricians and Gynecologists and the Society for Maternal-Fetal Medicine; Center for Disease Control and Prevention (CDC) recently recommended COVID-19 vaccination during or before pregnancy [44]. Apart from immunizing the pregnant female, the other advantage of vaccination during pregnancy is transmission of immunity to the newborn, though it still needs more research and evidence. The gestational age at which SARS-CoV-2 specific maternal antibodies are produced influences their detection in the cord blood, hence an earlier vaccination during pregnancy may give optimum results [45, 46]. Similarly, during lactation, it is unlikely that the vaccine lipid would enter the bloodstream and reach breast tissue; and even if it does, it is less likely that the intact nanoparticle or mRNA will enter the breast milk. In the unlikely event of mRNA present in milk, it is expected to be digested by the child and unlikely to cause any biological effect [47]. Hence, CDC considers vaccination safe even during breastfeeding [46].

\section{Duration of protection}

There is limited literature to comment on what is the maximum duration of protection from any of the COVID-19 vaccines. However, in a recent study by Gaebler et al. [48] on recipients of at least one dose of mRNA vaccine it was found that there was a 50 -fold increase in neutralizing capacity of anti-SARS-CoV-2 antibodies produced after vaccination and such antibodies may continue to evolve even up to one year. Another study on survivors of SARS-CoV-2 infection reported an even stronger immune response in terms of enhanced neutralizing antibodies, $\mathrm{T}$ cell immunity, and antibody-producing memory $\mathrm{B}$ cell response to 
S protein. These patients were followed up to 42 weeks of infection and up to 12 weeks of the first dose of the covid-19 vaccine [49]. However in a study on unvaccinated health care workers, it was found that their neutralizing antibodies were less active and less protective against SARS-CoV-2 variants [50]. Hence whatever data is available, it clearly states that individuals irrespective of their infection status should get vaccinated as it gives a bulletproof jacket against the virus.

\section{Combined vaccines against COVID-19}

The concept of mixing vaccines means giving the same or similar antigens of a microbe through two different types of vaccines. One vaccine is given as the first dose is utilized to prime the immune system and subsequent dosages of another vaccine are used as a booster of the immune response. The evidence for mixing COVID-19 vaccines and their impact is scarce as studies are still going on and their results are awaited. Recently, a few trials have been carried out to assess the efficacy of two vaccines if combined. A study reported Pfizer-BioNTech booster dose over Oxford-AstraZeneca was able to heighten the humoral immune response and antibodies produced could recognize and inactivate SARS-CoV-2 [51]. A randomized, phase II trial called 'CombiVacS' has found 150 times antibodies and a four-fold increase in the cellular immune response against SARS-CoV-2. In this study on 676 individuals, BNT162b2 (an mRNA vaccine) was given as a second dose after primary vaccination with ChAdOx1-S [52]. Few other ongoing observational trials are also finding similar results [53,54]. Even if all these reports show a positive outcome one cannot ignore the risks and adverse effects involved in vaccine mixing, i.e., increased fever, headache, joint pain, malaise, etc. Thus, a thorough evaluation of safety and efficacy versus adverse effects should be done before advocating combination vaccines. Recently, CDC has recommended and US Food and Drug Administration (US FDA) has authorised the third or booster dose of Pfizer after 6 months of completion of its second dose, the reason being the decrease in its efficacy after few months. Thus booster dose may be important especially for individuals with compromised immune system [55].

\section{Evidence advocating for COVID-19 vaccines}

Besides being highly contagious, COVID-19 can cause serious and life-threatening complications in all age groups. Social distancing, use of sanitizers and use of mask do provide some protection from virus exposure and spread but a more effective mechanism is required that can boost our immune system which can eliminate the virus on its entry into the body. The only such option available at present to keep us safe is a vaccine. Both past and present experience that we have gained through human and murine studies is helping us in designing an effective vaccine against SARS-CoV-2.

\section{Natural infection (human) and animal research evidence}

SARS-CoV-2 specific antibodies and cell-mediated immunity is set into the role to combat the circulating virions in COVID-19 infection. The majority of the patients develop antibodies against the RBD of immunodominant antigen (S protein) of SARS-CoV-2, and these antibodies are associated with antigen neutralizing activity [56]. The humoral response is directly proportional to the severity of COVID-19 infection, and the immunity declines over time after few months of infection $[57,58]$. Several studies have shown initial short-lived antibody response against SARS-CoV-2 $[59,60]$, and subsequent development of higher affinity antibody-secreting long lived plasma cells and memory B-cells [60-62]. A US based study, consisting longitudinal follow-up (at 1.3, 6.2 and 12 months after infection) of the 63 COVID-19 recovered subjects, and subset of vaccinated subjects $(n=26,41 \%)$, has explored the neutralizing breadth against SARS-CoV-2 over one year of period which is described subsequently [63]. It reported maintenance of anti-RBD antibodies above the geometric mean half-maximal neutralizing titer (NT50) between 6 to 12 months; however, nearly 30-fold raised anti-RBD IgG titers are seen among the vaccinated subjects. in contrast anti-nucleoprotein (anti-N) antibodies showed decremental trend irrespective of vaccination status between 6 to 12 months. Further, the researchers were also determined the neutralizing activity against a few variants of concern (B.1.1.7, B.1.351), and it found to be lower immune responsive towards variants of concern than against the 
wild-type SARS-CoV-2. After vaccination there was high neutralizing titers development among the concerns of variants [63].

There was 8-fold increase in RBD specific memory B cells among vaccinated subjects, and in contrast there was 1.35 -fold lower response (when compared to assay at 6 months) among unvaccinated participants at 1 year of follow-up. Authors also revealed that continued clonal evolution of anti-SARS-CoV-2 antibodies over 1 year period with resultant monoclonal antibodies against a wide group of variants [63].

\section{Congener viral research evidence}

Previous vaccine trials against SARS-CoV- 1 and Middle-East respiratory syndrome coronavirus (MERS-CoV) targeting $S$ protein, were utilized as ready reference evidence for rapid development and clinical use of the COVID-19 vaccines $[64,65]$. The development of "vaccine enhanced disease" which means increased production of non-neutralizing antibody responses following vaccination against SARS-CoV-1 and MERS-CoV, was an alarming issue from the animal study research [66]. However, a vaccine-enhanced disease-associated eosinophilic syndrome was not reported in a human trial with vaccines against SARS-CoV-1 and MERS-CoV.

\section{Epidemiological study evidence}

An observational study describing COVID-19 break on a fishing vessel was associated with a high attack rate (85.2\%) with single variant SARS-CoV-2. There were three subjects with prior COVID-19 pneumonia and neutralizing antibodies, and who experienced no symptoms as compared to the other infection naive subjects in the fishing vessel [67]. A population-based study from Italy reported lower incidence $(n=5,0.31 \%$ [95\% confidence interval (CI), 0.03-0.58\%]) of reinfection in post-COVID survivors ( $n=1579)$ [68]. Additionally, the same study also reported high incidence rate of new infection [ $n=528 / 13496,15.1 \%$ (95\% CI, 14.5-15.7\%)] among uninfected subjects in same population. The incidence density for 100,000 person days was $15.1 \%$ (95\% CI, 0.06-0.08\%) compared with 1.0 (95\% CI, 0.5-1.5\%) for re-infection [68]. A case control study has revealed 2.34 (95\% CI, 1.5-3.4\%) times the odds of reinfection among the unvaccinated subjects when compared with fully vaccinated subjects, and additionally it also reported no significant association of reinfection with partial vaccination status [69].

\section{Mechanisms of action of different vaccines}

The efficiency of a good vaccine is determined by its ability to generate long-term antibody responses by inducing plasma cells, in addition to the B cell and T cell memory. This immunological memory also known as 'trained immunity' by overcoming virus induced immune suppression and facilitating adaptive immune activation offers early viral clearance.

Broadly vaccines can be grouped in to 2 categories: live attenuated and subunit vaccines [70]. The attenuated vaccines work in a similar manner to the infectious agent. So far, no live attenuated vaccine is available for use against COVID-19. The recombinant virus vectors behave like an endogenous antigen. They are processed by APC and presented to T cells via MHC-I and generate cell mediated immune response. The RBD of S protein of these vaccine candidates contains major antigenic determinants which also induces production of neutralizing antibodies [71]. Adenovirus vector vaccines also work in similar fashion and induce potent antibody and cell mediated immune responses (72). DNA vaccines after entry in to the body are recognized by the innate immune sensors, e.g., stimulator of interferon genes (STING)/TANK-binding kinase 1 (TBK1)/IRF3 pathways, absent in melanoma 2 (AIM2) inflammasome, etc. which then activate both humoral and cellular immune responses [73]. Similarly, mRNA-based vaccine is recognized by various cell surface, endosomal or cytosolic receptors, e.g., TLR, RIG-I, nucleotide oligomerization domain (NOD)-like receptors, etc. [74]. Hence, the initial trigger to stimulate the immune system though different the end result for all types of vaccines is the same that is stimulation of immune system in more or less similar manner as done by the pathogen but without any harmful effects.

After vaccine injection the protein antigen or immunogen is recognized by the pattern recognition receptors, e.g., TLR present on a APC like DCs which engulf and process the vaccine antigen. The activated APC then move to draining lymph nodes. The APC then with the help of MHC-II molecules present the processed 
antigen to naive $\mathrm{CD} 4^{+} \mathrm{T}$ cells resulting in their activation. $\mathrm{T}$ cells then activate and promote development of B cells within the lymph node. During this B cells mature, undergo gene recombination process and differentiate in to plasma which after class switching produce large amount of high affinity vaccine antigen specific antibodies. This causes rapid increase in serum neutralizing antibody levels within first 2 weeks of vaccination. Simultaneously, some of the B cells become quiescent and differentiate in to memory B cells and develop immune memory. The APC through MHC-I and with the help of CD4 ${ }^{+} \mathrm{T}$ cells also activate cytotoxic T cells. Some of these CD8 ${ }^{+} \mathrm{T}$ cells become effector cells which others are reserved as CD8 ${ }^{+}$memory $\mathrm{T}$ cell. These memory cells during encounter with SARS-CoV-2 rapidly proliferate and facilitate elimination of pathogen [75].

\section{COVID-19 vaccine platforms}

Several different approaches are utilized to develop COVID-19 vaccines. These include, inactivated virus vaccine, live attenuated virus vaccine, recombinant virus vector vaccine, vector-based vaccines, DNA and mRNA based COVID vaccines. Inactivated virus vaccine is the easiest and a relatively rapid platform hence is most commonly employed for development of human vaccines. The different platforms of COVID-19 vaccines in preclinical and subclinical use are enlisted in Table 1.

Table 1. COVID-19 vaccine types available for current preclinical/clinical application and their manufactures

\begin{tabular}{|c|c|c|c|}
\hline No. & Vaccine types & Mechanism of vaccine development & Manufacturer \\
\hline 1 & Inactivated & $\begin{array}{l}\text { SARS-CoV- } 2 \text { grown in cell culture } \\
\text { Chemical inactivation of the virus } \\
\text { Combined with alum or another adjuvant }\end{array}$ & $\begin{array}{l}\text { Sinopharm + China National Biotec Group, Co + } \\
\text { Wuhan Institute of Biological Products, } \\
\text { COVAXIN (Bharat Biotech International Limited) }\end{array}$ \\
\hline 2 & Live attenuated & $\begin{array}{l}\text { Genetically weakened SARS-CoV-2 } \\
\text { SARS-CoV-2 grown in adverse conditions } \\
\text { Virulence is lost with maintained immunogenicity }\end{array}$ & - \\
\hline 3 & $\begin{array}{l}\text { Recombinant } \\
\text { virus vector }\end{array}$ & $\begin{array}{l}\text { Viral proteins (RBP, S protein) expressed on } \\
\text { mammalian cells, yeasts, or plants }\end{array}$ & NVX-CoV2373 (Novavax) \\
\hline 4 & Virus vector & $\begin{array}{l}\text { Genetically engineered vaccines } \\
\text { Use vectors uncommon to cause human } \\
\text { infections, e.g., chimpanzee adenovirus }\end{array}$ & - \\
\hline 4.1 & $\begin{array}{l}\text { Replication } \\
\text { incompetent } \\
\text { vector }\end{array}$ & $\begin{array}{l}\text { Engineered, to not replicate in vivo and express } \\
\text { the viral protein }\end{array}$ & $\begin{array}{l}\text { Ad26.COV2.S (Janssen/Johnson \& Johnson) } \\
\text { ChAdOx1 nCoV-19/AZD1222 (AstraZeneca/ } \\
\text { University of Oxford/Serum Institute of India) } \\
\text { Gam-COVID-Vac (Sputnik V) (Gamaleya Institute) }\end{array}$ \\
\hline 4.2 & $\begin{array}{l}\text { Replication } \\
\text { competent vector }\end{array}$ & $\begin{array}{l}\text { Engineered to express the spike protein and } \\
\text { replicate within the vaccinated individual }\end{array}$ & - \\
\hline 5 & $\begin{array}{l}\text { Nucleic acid } \\
\text { vaccines }\end{array}$ & $\begin{array}{l}\text { Exogenous nucleic acid is detected by innate } \\
\text { immune receptors which generate robust immune } \\
\text { response }\end{array}$ & - \\
\hline & DNA & $\begin{array}{l}\text { Plasmid DNA with mammalian expression } \\
\text { promotors and the target gene }\end{array}$ & Zydus Cadila (ZyCoV-D) [102] \\
\hline
\end{tabular}

RBP: receptor binding protein; -: not applicable/not available

\section{Immunogenicity and safety profile of the COVID vaccines in clinical use}

A high efficacy and safety of vaccine are the two critical factors for widespread acceptability and successful implementation of an immunization program against the COVID-19 pandemic [76]. Immunogenicity and safety of a vaccine are determined by several factors, i.e., type of vaccine, dose, timing of dose, route and site of administration, and vaccine handling conditions. Hence, it is worth discussing these aspects of potentially useful vaccines available against COVID-19 [77]. There are no absolute contra-indication for the COVID-19 vaccination, except to the subjects who showed anaphylaxis or allergic reactions towards the components of COVID-19 vaccine.

Vaccine-induced immune thrombocytopenia (VITT) is the most commonly reported adverse event following immunization (AEFI) with ChAdOx1 $\mathrm{nCoV}-19$ vaccine [78]. Arterial and venous thrombosis are the other AEFI reported with ChAdOx1 nCoV-19 vaccine [78]. Breakthrough infection following vaccination 
is another challenge that possibly results from the viral exposure during the period of inadequate immune response formation towards the vaccine, or if the viral infection is caused by varaints of concern that evade the immune response generated by the vaccine [78]. Nevertheless, the vaccines are shown to reduce the severity of the disease and the need of hospitalization. The different vaccine candidates, administration details and efficacies of vaccines approved for emergency use are enlisted in Table 2.

Table 2. Vaccines in clinical use/phase III trial, their routes of administration, dose, immunogenicity, safety profile, and authorized country

\begin{tabular}{|c|c|c|c|c|c|c|c|c|}
\hline Vaccine & Vaccine platform & Immunogen & Dosage & Route & Interval & Efficacy & Overall efficacy & Current EUA \\
\hline $\begin{array}{l}\text { BNT162b2 } \\
\text { Pfizer-BioNTech } \\
\text { (US) } \\
\text { [81-86] }\end{array}$ & mRNA & $\mathrm{SP}$ & $\begin{array}{l}30 \mu \mathrm{g}, 2 \\
\text { doses }\end{array}$ & IM & 21 days & $\begin{array}{l}88.9 \% \\
\text { after 1st } \\
\text { dose }\end{array}$ & $\begin{array}{l}52 \% \text { after } 1 \text { st } \\
\text { dose; } 94.6 \% \\
\text { after } 7 \text { days of } \\
2 \text { nd dose }\end{array}$ & $\begin{array}{l}\text { US, EU, } \\
\text { Canada, } \\
\text { and UK }\end{array}$ \\
\hline $\begin{array}{l}\text { mRNA-1273 } \\
\text { Moderna (US) } \\
{[87-89]}\end{array}$ & mRNA & SP & $\begin{array}{l}100 \mu \mathrm{g}, 2 \\
\text { doses }\end{array}$ & IM & 28 days & $\begin{array}{l}100 \% \\
\text { after } 14 \\
\text { days of } \\
\text { 2nd dose }\end{array}$ & $\begin{array}{l}92.1 \% \text { after } 14 \\
\text { days of } 1 \mathrm{st} \text { dose; } \\
94.1 \% \text { after } 14 \\
\text { days of } 2 \text { nd dose }\end{array}$ & $\begin{array}{l}\text { US, EU, } \\
\text { Canada, } \\
\text { and UK }\end{array}$ \\
\hline $\begin{array}{l}\text { Ad26.CoV2.S } \\
\text { Janssen/ } \\
\text { Johnson \& } \\
\text { Johnson (US) } \\
{[90,91]}\end{array}$ & $\begin{array}{l}\text { Recombinant, } \\
\text { replication } \\
\text { incompetent } \\
\text { human adenovirus } \\
\text { serotype } 26 \\
\text { vector }\end{array}$ & SP & $\begin{array}{l}5 \times 10^{10} \\
\text { viral } \\
\text { particles, } \\
\text { single } \\
\text { dose }\end{array}$ & IM & - & $\begin{array}{l}85 \% \\
\text { after } 28 \\
\text { days; } \\
100 \% \\
\text { after } 49 \\
\text { days }\end{array}$ & $\begin{array}{l}72 \% \text { in the US; } \\
66 \% \text { in Latin } \\
\text { America; } 57 \% \text { in } \\
\text { South Africa (at } \\
28 \text { day) }\end{array}$ & $\begin{array}{l}\text { US, EU, and } \\
\text { Canada }\end{array}$ \\
\hline $\begin{array}{l}\text { ChAdOx1 } \\
\text { (AZS1222) } \\
\text { AstraZeneca/ } \\
\text { Oxford (UK) } \\
{[92-94]}\end{array}$ & $\begin{array}{l}\text { Replication } \\
\text { deficient } \\
\text { chimpanzee } \\
\text { adenoviral vector }\end{array}$ & $\mathrm{SP}$ & $\begin{array}{l}5 \times 10^{10} \\
\text { viral } \\
\text { particles, } \\
2 \text { doses }\end{array}$ & IM & $\begin{array}{l}4 \text { to } 12 \\
\text { weeks }\end{array}$ & $\begin{array}{l}100 \% \\
\text { after } 21 \\
\text { days of } \\
1 \text { st dose }\end{array}$ & $\begin{array}{l}64.1 \% \text { after } 1 \text { st } \\
\text { dose; } 70.4 \% \\
\text { after } 14 \text { days of } \\
\text { 2nd dose }\end{array}$ & $\begin{array}{l}\text { UK, WHO/ } \\
\text { Covax, India, } \\
\text { and Mexico }\end{array}$ \\
\hline $\begin{array}{l}\text { Gam-COVID- } \\
\text { Vac (Sputnik V) } \\
{[97]}\end{array}$ & $\begin{array}{l}\text { Recombinant } \\
\text { adenovirus }\end{array}$ & GS & $\begin{array}{l}10^{11} \text { viral } \\
\text { particles, } \\
2 \text { doses }\end{array}$ & IM & 21 days & $\begin{array}{l}100 \% \\
\text { after } 21 \\
\text { days of } \\
\text { 1st dose }\end{array}$ & $\begin{array}{l}87.6 \% \text { after } 14 \\
\text { days of } 1 \mathrm{st} \text { dose; } \\
91.1 \% \text { after } 7 \\
\text { days of } 2 \text { nd dose }\end{array}$ & $\begin{array}{l}\text { Russia, } \\
\text { Belarus, } \\
\text { Argentina, } \\
\text { Serbia, Egypt, } \\
\text { Algeria, UAE, } \\
\text { and Palestine }\end{array}$ \\
\hline $\begin{array}{l}\text { Covaxin } \\
\text { (BBV152; } \\
\text { Bharat Biotech } \\
\text { and Ocugen) } \\
\text { [98] }\end{array}$ & $\begin{array}{l}\text { Whole-virion } \\
\text { inactivated }\end{array}$ & $\mathrm{SP}$ & $\begin{array}{l}6 \mu \mathrm{g} \text { of } \\
\text { whole } \\
\text { virions, } 2 \\
\text { doses }\end{array}$ & IM & 4 weeks & $\begin{array}{l}81 \% \\
\text { (phase } \\
\text { III interim } \\
\text { results) } \\
\text { after 2nd } \\
\text { dose }\end{array}$ & - & India \\
\hline
\end{tabular}

GS: glycoprotein spike; SP: spike protein; IM: intramuscular; EUA: Emergency Use Authorization

\section{BNT162b2 (Pfizer-BioNTech COVID-19 vaccine)}

It is a lipid nanoparticle-containing nucleoside-modified mRNA-based vaccine, which encodes the membrane-anchored, full-length SARS-CoV-2 S protein. It is administered via the IM, two doses at three weeks apart [79]. A randomized placebo-controlled, observer-blinded, dose-escalation phase I/II trial was conducted on the American population. There was the dose-dependent generation of neutralizing antibodies following BNT162b2 vaccine administration, and the geometric mean of the neutralizing antibodies in the study group was similar to the geometric mean of antibodies found in the convalescent plasma following mild to moderate COVID-19 infection [80]. Cross-immune response was also reported against other variants such as B.1.429, and B.1.35 (South Africa variant). A phase III clinical trial has reported a 95\% efficacy rate in preventing symptomatic COVID-19 infection at or after 7 days following the second dose of BNT162b2 vaccination [81]. The mild adverse events including local site reactions, headache, fever, fatigue, and myalgia were commonly reported particularly after the second dose of vaccination [82]. Anaphylaxis and Bell's palsy were the rare major adverse events reported following BNT162b2 vaccination [83, 84].

\section{mRNA-1273 (Moderna COVID-19 vaccine)}

It is also a lipid nanoparticle-containing nucleoside-modified (encoding S protein) mRNA-based vaccine and administered via IM route, two doses at four weeks apart. Dose-escalation, open-label phase I trial, reported 
a similar level of neutralizing antibodies in adult and older age group population, and geometric mean titer of the neutralizing antibodies was higher in a vaccinated group as compared to the geometric mean of antibodies in convalescent plasma donor sample [85]. The persistence of the high titers of neutralizing antibodies over 6 months following mRNA-1273 vaccination has been reported [86]. It showed an efficacy of $94.1 \%$ after 14 days following vaccination in phase III clinical trials [87], while adverse events were only mild including injection site pain and redness, headache, fever, fatigue, and myalgia. Anaphylaxis and Bell's palsy were the rare major adverse events related to the vaccination.

\section{Ad26.COV2.S (Janssen COVID-19 vaccine)}

It is a replication-incompetent adenovirus 26 vector-based vaccine, encoding full length, membrane-bound S protein (perfusion-stabilized conformation). It is administered as a single dose via IM route. Double-blind randomized phase I/II results showed high rates of neutralizing antibody production in subjects aged 18 to 85 years. However, the level of neutralizing antibody titers was slightly lesser than the level of antibodies in convalescent plasma [2]. Phase III clinical trials reported an efficacy of $66.9 \%$ against the development of moderate to severe COVID-19 infection after 14 days of vaccination [88]. Injection site pain, myalgia, headache, and fatigue were the commonly reported mild adverse events following vaccination. Urticaria, thromboembolic events, and tinnitus were noted in a small fraction of vaccinated subjects as compared to a placebo group.

\section{ChAdOx1 nCoV-19/AZD1222 (University of Oxford, AstraZeneca, and the Serum Institute of India)}

It is a replication-incompetent chimpanzee adenovirus vector-based vaccine with $S$ protein as an immunogen. Two doses are administered at an interval of 4 to 12 weeks apart. Single-blind, randomized control phase I/II trial has revealed high titer of neutralizing antibody at 28 days following vaccination irrespective of age strata in adults [89]. The cellular immune response is also detected following vaccination. Interim analysis of the multinational phase III trial has revealed a $70.4 \%$ efficacy rate at 14 days following 2 nd dose of vaccination [90]. Fatigue, headache, and fever were the commonly ( $8 \%)$ reported adverse events. The safety surveillance system has reported very rare events of vascular thrombosis (cerebral venous sinus thrombosis and splenic venous thrombosis), and severe thrombocytopenia particularly in women of between 30 to 60 years among vaccinated subjects. However, the adverse vascular events were lesser than the thrombotic events in the general population. In a recent study, Greinacher et al. [91] demonstrated immune thrombotic thrombocytopenia mediated by platelet-activating antibodies against platelet factor 4 (PF4) in 11 patients who developed thrombotic events following "ChAdOx1 nCov-19" vaccination.

Authors are of the opinion that, even though rarely, the recombinant vector-based vaccines might be inducing COVID-19 like illness, and prothrombotic events as observed in COVID-19. It can also explain why some people develop fever and turn reverse transcription-polymerase chain reaction (RT-PCR) positive after first or second dose of vector vaccine. Occasional sudden deaths secondary to thrombotic events have also been reported following this vaccination [91]. However, this hypothesis needs to be validated by further research on animal studies and conducting autopsies in patients with sudden death after taking "ChAdOx1 nCov-19" vaccine [91]. As of now, thrombotic events are conspicuously being reported only following vector-based vaccine administration.

\section{NVX-CoV2373 (Novavax)}

It is a nanoparticle, recombinant protein vaccine containing $\mathrm{S}$ protein and Matrix-M1 adjuvant. It is administered intramuscularly, two doses at 21 days of interval. Randomized placebo-controlled phase I/II trial reported high levels of neutralizing antibodies following the adjuvant vaccine as compared to the mean antibody titer of convalescent sera from hospitalized subjects [92]. Phase III trial showed $89.3 \%$ of efficacy at 7 days after the 2 nd dose of vaccination [93]. Fatigue, headache, and myalgia were the commonly reported adverse events following vaccination. 


\section{Gam-COVID-Vac/Sputnik V (Gamaleya Institute)}

It is a two-replication incompetent adenovirus vector-based vaccine containing the gene that encode full-length S protein. It is administered in two doses at an interval of 3 weeks apart, via IM route. An open-label, randomized phase I/II clinical trial reported high neutralizing antibody titer following vaccination. Interim analysis of the phase III trial results showed a $91.6 \%$ of efficacy rate at 21 days following 1st dose of vaccination [94]. Flu-like symptoms were the most commonly reported adverse events following vaccination.

\section{Covaxin (BBV152; Bharat Biotech and Ocugen)}

It is an an inactivated whole-virion SARS-CoV-2 vaccine, administered in two doses via IM route, 4 weeks apart. Interim analysis of the phase III trial results showed $81 \%$ overall efficacy after 2nd dose [95]. Local injection site swelling, malaise, headache, and fever are the minor adverse events reported after vaccination.

\section{Viral mutation and COVID-19 vaccines}

Mutations in the SARS-CoV-2 genome result in the development of new viral variants which are different from the predominant virus isolated from the population. Viral variants cause decreased efficacy of the vaccines and results in low protection against severe infection. The B.1.1.7 (UK variant), B.1.351 (South Africa variant), and B.1.1.28 (Brazil variant) are the most common variants of concern reported to date. BNT162b2 and mRNA-1273 vaccines showed maintained neutralizing antibodies against B.1.1.7 strain in vitro studies, however, significant reduction of neutralizing antibody level encountered with B.1.351 [96-98]. Based on the in vitro studies a few researchers advised the development of a new strain-specific vaccine against the South African variant. Ad26.COV2.S vaccine has produced consistent high neutralizing antibodies against the native strain and new variants, including B.1.351 strain [99]. ChAdOx1 nCoV-19/AZD1222 vaccination halted in South Africa due to its minimal efficacy ( 21.9\%) against protection against B.1.351 infection [100]. A double mutant strain called Lineage B.1.617 has recently been reported from India, and vaccination with BBV152 (Covaxin) has been found to offer a reasonable protection against it [101].

\section{Conclusion}

Vaccination is the most critical strategy to curb the COVID-19 pandemic. Most phase III clinical trials have shown adequate efficacy of the vaccines against the development of COVID-19 infection and severe disease. The neutralizing antibodies are short-lived, and there is evidence of long-term memory immune cells in circulation following the previous coronavirus epidemic (SARS, MERS). Longitudinal vaccine trials are yet to confirm the productivity and duration of memory B cells following SARS-CoV-2 infection. However, the emergence of new variants of concern may result in hampered susceptibility towards post-infection or post-vaccination mounted immunity, and threaten the progress of vaccination drive. A universal vaccine design must account for cross-immune response against the new variants in addition to the predominant SARS-CoV-2 strain.

\section{Abbreviations}

ACE-2: angiotensin-converting enzyme 2

APCs: antigen-presenting cells

CDC: Center for Disease Control and Prevention

CI: confidence interval

COVID-19: coronavirus disease 2019

CXCL1: chemokine (C-X-C motif) ligand 1

DCs: dendritic cells

E: envelope

GS: glycoprotein spike 
IFNs: interferons

IgG: immunoglobulin G

IL-6: interleukin 6

IM: intramuscular

JAK/STAT: Janus kinase/signal transducer and activator of transcription

M: membrane

MCP-1: monocyte chemotactic protein-1

MERS-CoV: Middle-East respiratory syndrome coronavirus

MHC-I: major histocompatibility complex class I

$\mathrm{N}$ : nucleocapsid

NF-кB: nuclear factor-kappaB

PRR: pattern recognition receptors

RBD: receptor-binding domain

S: spike

SARS-CoV-2: severe acute respiratory syndrome coronavirus 2

SP: spike protein

ssRNA: single stranded ribonucleic acid

TLRs: Toll-like receptors

TNF- $\alpha$ : tumour necrosis factor alpha

WHO: World Health Organization

\section{Declarations}

\section{Author contributions}

MG and MM: conception, drafting, organizing, revision, and final approval of the manuscript; SG, VS and IPS: drafting, organizing, revision, and final approval of the manuscript; HB: illustrations, drafting, revision, and final approval of the manuscript; YK: drafting, organizing, revision, and final approval of the manuscript.

\section{Conflicts of interest}

The authors declare that they have no conflicts of interest.

\section{Ethical approval}

Not applicable.

\section{Consent to participate}

Not applicable.

\section{Consent to publication}

Not applicable.

Availability of data and materials

Not applicable.

\section{Funding}

Not applicable.

\section{Copyright}

(C) The Author(s) 2021. 


\section{References}

1. who.int [Internet]. Draft landscape of COVID-19 candidate vaccines. c2021 WHO [cited 2021 Apr 11]. Available from: https://www.who.int/publications/m/item/draft-landscape-of-covid19-candidate-vaccines

2. Sadoff J, Gars ML, Shukarev G, Heerwegh D, Truyers C, de Groot AM, et al. Interim results of a phase 1-2a trial of Ad26.COV2.S Covid-19 vaccine. N Engl J Med. 2021;384:1824-35.

3. Fehr AR, Perlman S. Coronaviruses: an overview of their replication and pathogenesis. Methods Mol Biol. 2015;1282:1-23.

4. Marra MA, Jones SJ, Astell CR, Holt RA, Brooks-Wilson A, Butterfield YS, et al. The genome sequence of the SARS-associated coronavirus. Science. 2003;300:1399-404.

5. Li F. Structure, function, and evolution of coronavirus spike proteins. Annu Rev Virol. 2016;3:237-61.

6. Huang Y, Yang C, Xu XF, Xu W, Liu SW. Structural and functional properties of SARS-CoV-2 spike protein: potential antivirus drug development for COVID-19. Acta Pharmacol Sin. 2020;41:1141-9.

7. Zhang YZ, Holmes EC. A genomic perspective on the origin and emergence of SARS-CoV-2. Cell. 2020;181223-7.

8. Wu A, Peng Y, Huang B, Ding X, Wang X, Niu P, et al. Genome composition and divergence of the novel coronavirus (2019-nCoV) originating in China. Cell Host Microbe. 2020;27:325-8.

9. Jeyanathan M, Afkhami S, Smaill F, Miller MS, Lichty BD, Xing Z. Immunological considerations for COVID-19 vaccine strategies. Nat Rev Immunol. 2020;20:615-32.

10. Ahmed SF, Quadeer AA, McKay MR. Preliminary identification of potential vaccine targets for the COVID-19 coronavirus (SARS-CoV-2) based on SARS-CoV immunological studies. Viruses. 2020;12:254-60.

11. Gao Y, Yan L, Huang Y, Liu F, Zhao Y, Cao L, et al. Structure of the RNA-dependent RNA polymerase from COVID-19 virus. Science. 2020;368:779-82.

12. ecdc.europa.eu [Internet]. Immune responses and immunity to SARS-CoV-2 2020. c European Centre for Disease Prevention and Control (ECDC) 2021 [cited 2021 Apr 11]. Available from: https://www.ecdc. europa.eu/en/covid-19/latest-evidence/immune-responses

13. Zhu N, Zhang D, Wang W, Li X, Yang B, Song J, et al. A novel coronavirus from patients with pneumonia in China, 2019. N Engl J Med. 2020;382:727-33.

14. Perlman S, Dandekar AA. Immunopathogenesis of coronavirus infections: implications for SARS. Nat Rev Immunol. 2005;5:917-27.

15. Hur S. Double-stranded, sensors and modulators in innate immunity. Annu Rev Immunol. 2019;37:349-75.

16. Chu H, Chan JFW, Wang Y, Yuen TTT, Chai Y, Hou Y, et al. Comparative replication and immune activation profiles of SARS-CoV-2 and SARS-CoV in human lungs: an ex vivo study with implications for the pathogenesis of COVID-19. Clin Infect Dis. 2020;71:223-34.

17. Wang W, Ye L, Ye L, Li B, Gao B, Zeng Y, et al. Up-regulation of IL-6 and TNFalpha induced by SARS-coronavirus spike protein in murine macrophages via NFkappaB pathway. Virus Res. 2007;128:1-8.

18. Blanco-Melo D, Nilsson-Payant BE, Liu WC, Uhl S, Hoagland D, Moller R, et al. Imbalanced host response to SARS-CoV-2 drives development of COVID-19. Cell. 2020;181:1036-45.e9.

19. Glowacka I, Bertram S, Herzog P, Pfefferle S, Steffen I, Muench MO, et al. Differential downregulation of ACE2 by the spike proteins of severe acute respiratory syndrome coronavirus and human coronavirus NL63. J Virol. 2010;84:1198-205.

20. Mohammad MHS. Immune response scenario and vaccine development for SARS-CoV-2 infection. Int Immunopharmacol. 2021;94:107439. 
21. Prompetchara E, Ketloy C, Palaga T. Immune responses in COVID-19 and potential vaccines: lessons learned from SARS and MERS epidemic. Asian Pac J Allergy Immunol. 2020;38:1-9.

22. Chaplin DD. Overview of the immune response. J Allergy Clin Immunol. 2010;125 Suppl 2:3-23.

23. Shah VK, Firmal P, Alam A, Ganguly D, Chattopadhyay S. Overview of immune response during SARS-CoV-2 infection: lessons from the past. Front Immunol. 2020;11:1949.

24. Chen J, Subbarao K. The Immunobiology of SARS*. Annu Rev Immunol. 2007;25:443-72.

25. Cameron MJ, Ran L, Xu L, Danesh A, Bermejo-Martin JF, Cameron CM, et al. Interferon-mediated immunopathological events are associated with atypical innate and adaptive immune responses in patients with severe acute respiratory syndrome. J Virol. 2007;81:8692-706.

26. Guo Y, Sun S, Wang K, Zhang S, Zhu W, Chen Z. Elicitation of immunity in mice after immunization with the S2 subunit of the severe acute respiratory syndrome coronavirus. DNA Cell Biol. 2005;24:510-5.

27. Huang J, Cao Y, Du J, Bu X, Ma R, Wu C. Priming with SARS CoV S DNA and boosting with SARS $\mathrm{CoV} S$ epitopes specific for $\mathrm{CD}^{+}$and $\mathrm{CD}^{+} \mathrm{T}$ cells promote cellular immune responses. Vaccine. 2007;25:6981-91.

28. Amanat F, Krammer F. SARS-CoV-2 vaccines: status report. Immunity. 2020;52:583-9.

29. Du L, Zhao G, Lin Y, Sui H, Chan C, Ma S, et al. Intranasal vaccination of recombinant adeno-associated virus encoding receptor-binding domain of severe acute respiratory syndrome coronavirus (SARS-CoV) spike protein induces strong mucosal immune responses and provides long-term protection against SARS-CoV infection. J Immunol. 2008;180:948-56.

30. Chung JY, Thone MN, Kwon YJ. COVID-19 vaccines: the status and perspectives in delivery points of view. Adv Drug Deliv Rev. 2021;170:1-25.

31. Sonani B, Aslam F, Goyal A, Patel J, Bansal P. COVID-19 vaccination in immunocompromised patients. Clin Rheumatol. 2021;40:797-8.

32. Pollard AJ, Bijker EM. A guide to vaccinology: from basic principles to new developments. Nat Rev Immunol. 2021;1:83-100.

33. Peng Y, Mentzer AJ, Liu G, Yao X, Yin Z, Dong D, et al. Broad and strong memory CD $4^{+}$and CD8 $8^{+}$ cells induced by SARS-CoV-2 in UK convalescent individuals following COVID-19. Nat Immunol. 2020;21:1336-45.

34. Liu W, Liu L, Kou G, Zheng Y, Ding Y, Ni W, et al. Evaluation of nucleocapsid and spike protein-based enzyme linked immunosorbent assays for detecting antibodies against SARS-CoV-2. J Clin Microbiol. 2020;58:e00461-20.

35. Pinto MV, Bihari S, Snape MD. Immunisation of the immunocompromised child. J Infect. 2016;72 Suppl:S13-22.

36. cidrap.umn.edu [Internet]. COVID-19 vaccines shown to protect at-risk patients. c2021 Regents of the University of Minnesota [cited 2021 Jul 12]. Available from: https://www.cidrap.umn.edu/newsperspective/2021/07/covid-19-vaccines-shown-protect-risk-patients

37. Chavarot N, Ouedrani A, Marion O, Leruez-Ville M, Vilain E, Baaziz M, et al. Poor anti-SARS-CoV-2 Hhumoral and T-cell responses after 2 injections of mRNA vaccine in kidney transplant recipients treated with belatacept. Transplantation. 2021;32:1053-5.

38. Boyarsky BJ, Werbel WA, Avery RK, Tobian AAR, Massie AB, Segev DL, et al. Antibody response to 2-dose SARS-CoV-2 mRNA vaccine series in solid organ transplant recipients. JAMA. 2021;325:2204-6.

39. Rozen-Zvi B, Yahav D, Agur T, Zingerman B, Ben-Zvi H, Atamna A, et al. Antibody response to SARS-CoV-2 mRNA vaccine among kidney transplant recipients: a prospective cohort study. Clin Microbiol Infect. 2021;11:1173.e1-1173.

40. Grupper A, Sharon S, Finn T, Cohen R, Israel M, Agbaria A, et al. Humoral response to the Pfizer BNT162b2 vaccine in patients undergoing maintenance hemodialysis. Clin J Am Soc Nephrol. 2021;325:1037-42. 
41. Barrière J, Chamorey E, Adjtoutah Z, Castelnau O, Mahamat A, Marco S, et al. Impaired immunogenicity of BNT162b2 anti-SARS-CoV-2 vaccine in patients treated for solid tumors. Ann Oncol. 2021;32:1053-5.

42. Kennedy NA, Lin S, Goodhand JR, Chanchlani N, Hamilton B, Bewshea C, et al. Infliximab is associated with attenuated immunogenicity to BNT162b2 and ChAdOx1 nCoV-19 SARS-CoV-2 vaccines in patients with IBD. Gut. 2021;70:1884-93.

43. Loubet P, Wittkop L, Tartour E, Parfait B, Barrou B, Blay JY, et al. A French cohort for assessing COVID-19 vaccine responses in specific populations. Nat Med. 2021;27:1319-21.

44. cdc.gov [Internet]. COVID-19 vaccines while pregnant or breastfeeding. [cited 2021 Sept 25]. Available from: https://www.cdc.gov/coronavirus/2019-ncov/vaccines/recommendations/pregnancy.html

45. Adhikari EH, MorenoW, Zofkie AC, MacDonald L, McIntire DD, Collins RRJ, et al. Pregnancy outcomes among women with and without severe acute respiratory syndrome coronavirus 2 infection. JAMA Netw Open. 2020;3:e2029256.

46. Adhikari EH, Spong CY. COVID-19 Vaccination in pregnant and lactating women. JAMA. 2021;325:1039-40.

47. Stuebe A. Considerations for COVID-19 vaccination in lactation. Breastfeed Med. 2021;16:2.

48. Gaebler C, Wang Z, Lorenzi JCC, Muecksch F, Finkin S, Tokuyama M, et al. Evolution of antibody immunity to SARS-CoV-2. Nature. 2021;591:639-44.

49. Reynolds CJ, Pade C, Gibbons JM, Butler DK, Otter AD, Menacho K, et al. Prior SARS-CoV-2 infection rescues $B$ and $T$ cell responses to variants after first vaccine dose. Science. 2021;372:1418-23.

50. Abbasi J. Study suggests lasting immunity after COVID-19, with a big boost from vaccination. JAMA. 2021;326:376-7.

51. Callaway E. Mix-and-match COVID vaccines trigger potent immune response. Nature. 2021;593:491.

52. Borobia AM, Carcas AJ, Pérez-Olmeda M, Castaño L, Bertran MJ, García-Pérez J, et al. Immunogenicity and reactogenicity of BNT162b2 booster in ChAdOx1-S-primed participants (CombiVacS): a multicentre, open-label, randomised, controlled, phase 2 trial. Lancet. 2021;398:121-30.

53. Shaw RH, Stuart A, Greenland M, Liu X, Nguyen Van-Tam JS, Snape MD, et al. Heterologous prime-boost COVID-19 vaccination: initial reactogenicity data. Lancet. 2021;397:2043-6.

54. Kunal S, Sakthivel P, Gupta N, Ish P. Mix and match COVID-19 vaccines: potential benefit and perspective from India. Postgrad Med J. 2021; [Epub ahead of print].

55. cdc.gov [Internet]. COVID-19 vaccines for moderately to severely immunocompromised people. [cited 2021 Sept 25]. Available from: https://www.cdc.gov/coronavirus/2019-ncov/vaccines/ recommendations/immuno.html

56. To KKW, Tsang OTY, Leung WS, Tam AR, Wu TC, Lung DC, et al. Temporal profiles of viral load in posterior oropharyngeal saliva samples and serum antibody responses during infection by SARS-CoV-2: an observational cohort study. Lancet Infect Dis. 2020;20:565-74.

57. Rijkers G, Murk JL, Wintermans B, van Looy B, van den Berge M, Veenemans J, etal. Differences in antibody kinetics and functionality between severe and mild severe acute respiratory syndrome coronavirus 2 infections. J Infect Dis. 2020;222:1265-9.

58. Wang K, Long QX, Deng HJ, Hu J, Gao QZ, Zhang GJ, et al. Longitudinal dynamics of the neutralizing antibody response to SARS-CoV-2 infection. Clin Infect Dis. 2021;73:e531-9.

59. Robbiani DF, Gaebler C, Muecksch F, Lorenzi JCC, Wang Z, Cho A, et al. Convergent antibody responses to SARS-CoV-2 in convalescent individuals. Nature. 2020;584:437-42.

60. Dan JM, Mateus J, Kato Y, Hastie KM, Yu ED, Faliti CE, et al. Immunological memory to SARS-CoV-2 assessed for up to 8 months after infection. Science. 2021;371:eabf4063.

61. Rodda LB, Netland J, Shehata L, Pruner KB, Morawski PA, Thouvenel C, et al. Functional SARS-CoV-2-specific immune memory persists after mild COVID-19. Cell. 2021;184:169-83. 
62. Zhu FC, Li YH, Guan XH, Hou LH, Wang WJ, Li JX, et al. Safety, tolerability, and immunogenicity of a recombinant adenovirus type-5 vectored COVID-19 vaccine: a dose-escalation, open-label, non-randomized, first-in-human trial. Lancet. 2020;395:1845-54.

63. Wang Z, Muecksch F, Schaefer-Babajew D, Finkin S, Viant C, Gaebler C, et al. Naturally enhanced neutralizing breadth against SARS-CoV-2 one year after infection. Nature. 2021:595:426-31.

64. Lin JT, Zhang JS, Su N, Xu JG, Wang N, Chen JT, et al. Safety and immunogenicity from a phase I trial of inactivated severe acute respiratory syndrome coronavirus vaccine. Antivir Ther. 2007;12:1107-13.

65. Modjarrad K, Roberts CC, Mills KT, Castellano AR, Paolino K, Muthumani K, et al. Safety and immunogenicity of an anti-Middle East respiratory syndrome coronavirus DNA vaccine: a phase 1, open-label, single-arm, dose-escalation trial. Lancet Infect Dis. 2019;19:1013-22.

66. Halstead SB, Katzelnick L. COVID-19 Vaccines: should we fear ADE? J Infect Dis. 2020;222:1946-50.

67. Addetia A, Crawford KHD, Dingens A, Zhu H, Roychoudhury P, Huang ML et al. Neutralizing antibodies correlate with protection from SARS-CoV-2 in humans during a fishery vessel outbreak with a high attack rate. J Clin Microbiol. 2020;58:e02107-20.

68. Vitale J, Mumoli N, Clerici P, De Paschale M, Evangelista I, Cei M, et al. Assessment of SARS-CoV-2 reinfection 1 year after primary infection in a population in Lombardy, Italy. JAMA Intern Med. 2021:181:1407-8

69. Cavanaugh AM, Spicer KB, Thoroughman D, Glick C, Winter K. Reduced risk of reinfection with SARS-CoV-2 after COVID-19 vaccination-Kentucky, May-June 2021. MMWR Morb Mortal Wkly Rep. 2021;70:1081-3.

70. Pulendran B, Ahmed R. Immunological mechanisms of vaccination. Nat Immunol. 2011;12:509-17.

71. Bonavia A, Zelus BD, Wentworth DE, Talbot PJ, Holmes KV. Identification of a receptor-binding domain of the spike glycoprotein of human coronavirus HCoV-229E. J Virol. 2003;77:2530-8.

72. Tan WG, Jin HT, West EE, Penaloza-MacMaster P, Wieland A, Zilliox MJ, et al. Comparative analysis of simian immunodeficiency virus gag-specific effector and memory $C D 8^{+} \mathrm{T}$ cells induced by different adenovirus vectors. J Virol. 2013;87:1359-72.

73. Li L, Petrovsky N. Molecular mechanisms for enhanced DNA vaccine immunogenicity. Exp Rev Vaccines. 2016;15:313-29.

74. Pandey SC, Pande V, Sati D, Upreti S, Samant M. Vaccination strategies to combat novel corona virus SARS-CoV-2. Life Sci. 2020;256:117956.

75. Pollard AJ, Bijker EM. A guide to vaccinology: from basic principles to new developments. Nat Rev Immunol. 2021;21:83-100.

76. Kandeil A, Mostafa A, Hegazy RR, El-Shesheny R, Taweel AE, Gomaa MR, et al. Immunogenicity and safety of an inactivated SARS-CoV-2 vaccine: preclinical studies. Vaccines. 2021;9:214.

77. Strikas RA, Mawle AC, Pickering LK, Orenstein WA. Chapter 6-Active immunization. In: Long SS, Prober CG, Fischer M, editors. Principles and practice of pediatric infectious diseases (5th edition). ELSEVIER; 2018. pp. 43-71. e4.

78. Bhatia R, Abraham P. COVID-19 vaccines \& pandemic. Indian J Med Res. 2021;153:517-21.

79. fda.gov [Internet]. Emergency Use Authorization (EUA) of the Pfizer-BioNTech COVID-19 vaccine to prevent coronavirus. Fact sheet for healthcare providers administering vaccine. [cited 2021 Apr 12]. Available from: https://www.fda.gov/media/144413/download

80. Walsh EE, Frenck RW Jr, Falsey AR, Kitchin N, Absalon J, Gurtman A, et al. Safety and immunogenicity of two RNA-based Covid-19 vaccine candidates. N Engl J Med. 2020;383:2439-50.

81. Polack FP, Thomas SJ, Kitchin N, Absalon J, Gurtman A, Lockhart S, et al. Safety and efficacy of the BNT162b2 mRNA Covid-19 vaccine. N Engl J Med. 2020;383:2603-15. 
82. Chapin-Bardales J, Gee J, Myers T. Reactogenicity following receipt of mRNA-based COVID-19 vaccines. JAMA. 2021;325:2201-2.

83. cdc.gov [Internet]. COVID-19 vaccine safety update, Advisory Committee on Immunization Practices (ACIP) meeting, January 27, 2021. [cited 2021 Apr 12]. Available from: https://www.cdc.gov/vaccines/ acip/meetings/downloads/slides-2021-01/06-COVID-Shimabukuro.pdf

84. fda.gov [Internet]. Pfizer-BioNTech COVID-19 vaccine. Vaccines and related biological products advisory committee meeting. [cited $2021 \mathrm{Apr}$ 12]. Available from: https://www.fda.gov/ media/144245/download

85. Anderson EJ, Rouphael NG, Widge AT, Jackson LA, Roberts PC, Makhene M, et al. Safety and immunogenicity of SARS-CoV-2 mRNA-1273 vaccine in older adults. N Engl J Med. 2020;383:2427-38.

86. Doria-Rose N, Suthar MS, Makowski M, O'Connell S, McDermott AB, Flach B, et al. Antibody persistence through 6 months after the second dose of mRNA-1273 vaccine for Covid-19. N Engl J Med. 2021;383:2427-38.

87. Baden LR, El Sahly HM, Essink B, Kotloff K, Frey S, Novak R, et al. Efficacy and safety of the mRNA-1273 SARS-CoV-2 vaccine. N Engl J Med. 2021;384:403-16.

88. fda.gov [Internet]. Janssen Ad26.COV2.S vaccine for the prevention of COVID-19. Vaccines and related biological products advisory committee meeting, February 26, 2021. [cited 2021 Apr 12]. Available from: https://www.fda.gov/media/146217/download

89. Folegatti PM, Ewer KJ, Aley PK, Angus B, Becker S, Belij-Rammerstorfer S, et al. Safety and immunogenicity of the ChAdOx1 $\mathrm{nCoV}-19$ vaccine against SARS-CoV-2: a preliminary report of a phase 1/2, single-blind, randomized controlled trial. Lancet. 2020;396:467-78.

90. Voysey M, Clemens SAC, Madhi SA, Weckx LY, Folegatti PM, Aley PK, et al. Safety and efficacy of the ChAdOx1 nCoV-19 vaccine (AZD1222) against SARS-CoV-2: an interim analysis of four randomized controlled trials in Brazil, South Africa, and the UK. Lancet. 2021;397:99-111.

91. Greinacher A, Thiele T, Warkentin TE, Weisser K, Kyrle PA, Eichinger S. Thrombotic thrombocytopenia after ChAdOx1 nCov-19 vaccination. N Engl J Med. 2021;384:2092-101.

92. Keech C, Albert G, Cho I, Robertson A, Reed P, Neal S, et al. Phase 1-2 trial of a SARS-CoV-2 recombinant spike protein nanoparticle vaccine. N Engl J Med. 2020;383:2320-32.

93. novavax.com [Internet]. Novavax COVID-19 vaccine demonstrates $89.3 \%$ efficacy in UK phase 3 trial. [cited 2021 Apr 12]. Available from: https://ir.novavax.com/news-releases/news-release-details/ novavax-covid-19-vaccine-demonstrates-893-efficacy-uk-phase-3

94. Logunov DY, Dolzhikova IV, Zubkova OV, Tukhvatulin AI, Shcheblyakov DV, Dzharullaeva AS, et al. Safety and immunogenicity of an rAd26 and rAd5 vector-based heterologous prime-boost COVID-19 vaccine in two formulations: two open, non-randomized phase 1/2 studies from Russia. Lancet. 2020;396:887-97.

95. bharatbiotech.com [Internet]. Bharat Biotech announces phase 3 results of COVAXIN $^{\circledR}$ : India's first COVID-19 vaccine demonstrates interim clinical efficacy of 81\%. [cited 2021 Aug 26]. Available from: https://www.bharatbiotech.com/images/press/covaxin-phase3-efficacy-results.pdf

96. Liu Y, Liu J, Xia H, Zhang X, Fontes-Garfias CR, Swanson KA, et al. Neutralizing activity of BNT162b2-elicited serum-preliminary report. N Engl J Med. 2021;384:1466-8.

97. Muik A, Wallisch AK, Sänger B, Swanson KA, Mühl J, Chen W, et al. Neutralization of SARS-CoV-2 lineage B.1.1.7 pseudovirus by BNT162b2 vaccine-elicited human sera. Science. 2021;371:1152-3.

98. Wu K, Werner AP, Koch M, Choi A, Narayanan E, Stewart-Jones GBE, et al. Serum neutralizing activity elicited by mRNA-1273 vaccine. N Engl J Med. 2021;384:1468-70.

99. fda.gov [Internet]. COVID-19 vaccine Ad26.COV2.S sponsor briefing document for the FDA vaccines and related biological products advisory committee. [cited 2021 Apr 12]. Available from: https://www.fda. gov/media/146217/download 
100. Madhi SA, Baillie V, Cutland CL, Voysey M, Koen AL, Fairlie L, et al. Efficacy of the ChAdOx1 nCoV-19 Covid-19 vaccine against the B.1.351 variant. N Engl J Med. 2021;384:1885-98.

101. Yadav PD, Sapkal GN, Abraham P, Ella R, Deshpande G, Patil DY, et al. Neutralization of variant under investigation B.1.617 with sera of BBV152 vaccinees. Clin Infect Dis. 2021;[Epub ahead of print].

102. Momin T, Kansagra K, Patel H, Sharma S, Sharma B, Patel J, et al. Safety and immunogenicity of a DNA SARS-CoV-2 vaccine (ZyCoV-D): results of an open-label, non-randomized phase I part of phase I/II clinical study by intradermal route in healthy subjects in India. EClinicalMedicine. 2021;38:101020. 